\title{
Message from the 2017 Program Chair
}

Published online: 3 January 2018

(C) International Association of Medical Science Educators 2018
Dear Friends and Colleagues,

It is with great enthusiasm that the Program Committee for the 21 st annual meeting of the International Association of Medical Science Educators (IAMSE), held in Burlington, VT, USA, on June 10-13, 2017, presents these conference proceedings.

The 2017 annual meeting was truly one for the record books. First, this year marked the 20th anniversary of the founding of IAMSE and we celebrated the occasion by honoring IAMSE Founder, Dr. Roger Koment. Second, meeting registration numbers were the highest in the organization's history. The response to this year's theme, "Delivering Evidence-Based Health Sciences Education," was impressive. The outstanding plenary presentations enlarged our understanding of the research on learning and cognition. The high-quality conference sessions, oral presentations, and posters demonstrated application of these research-derived principles and challenged us to make changes in our own work as educators. Finally, and thanks to the efforts of the Student Research Committee, we benefited from the participation of learners and welcomed them as future colleagues into our conference and organization.

This issue of Medical Science Educator presents to you, our readers, a compilation of plenary speaker presentations in addition to the abstracts from our meeting's oral and poster submissions. The mission of IAMSE is to advance health profession education through teacher development and to ensure that the teaching and learning of medical science continues to be firmly grounded in foundational sciences and the best practices of teaching. This year's meeting exemplified the mission through its offerings of timely and innovative Preconference Workshops, Faculty Development Courses, Plenary Sessions, Concurrent Focus Sessions, Poster Viewing Sessions, and Poster Discussion Sessions. Recipients of the IAMSE Master Scholar, Master Teacher, Educational Scholarship, Student and Faculty Travel, Oral Presentation, and Poster Presentation awards truly represent the outstanding accomplishments and contributions of our members. Future education leaders participated in the Essential Skills in Medical Education Program and Educational Scholarship Fellowship Program.

IAMSE's members are international leaders, innovators, and scholars in health sciences education. The work presented in this issue represents evidence-informed curricula, instructional strategies, assessment methods, faculty development, and technology for teaching. We hope they inspire you in your own academic and scholarly efforts. Please join us for our next annual meeting June 9-12, 2018, in Henderson, NV, USA. We look forward to seeing you there!

Kathryn N. Huggett, Ph.D.

Chair, 2017 Program Planning Committee. 